\title{
Cumhurbaşkanlığı Hükümet Sisteminin Türkiye Cumhuriyeti İdari Teşkilatına Getirdiği Yenilikler*
}

\author{
Innovations Brought by the Presidential Government System to the Administrative Organization of the Republic of \\ Turkey
}

\author{
Abdülkadir Özdemir**1
}

${ }^{1}$ Tercan Vocational School, Erzincan Binali Yıldırım University, Erzincan, Turkey

\begin{abstract}
Received: 01.07.2021
Accepted: 20.09 .2021

This article was checked by intihal.net

\section{Öz}

Türkiye'de 16 Nisan 2017 tarihinde kabul edilen referandum sonucunda hükümet sistemi değişmiş ve 24 Haziran 2018 tarihinde yapılan seçimler sonucunda 9 Temmuz 2018 tarihinde Cumhurbaşkanının yemin ederek göreve başlamasıyla birlikte Cumhurbaşkanlığı hükümet sistemi fiili olarak uygulanmaya başlanmıştır. Cumhurbaşkanlığı hükümet sistemi sadece yasama, yürütme ve yargı kuvvetleri arasındaki ilişkilere değil, aynı zamanda Türkiye Cumhuriyeti'nin idari teşkilatına da önemli yenilikler getirmiştir. Yeni hükümet sistemi başkanlık sistemine çok benzese de ABD'de uygulanan başkanlık sistemi ile birebir aynı değildir. Başkanlık sistemlerinin en önemli özellikleri tek başlı yürütmenin ve geniş yetkilerle donatılış bir devlet başkanının olmasıdır. Bu özellikler Cumhurbaşkanlığı hükümet sisteminin de temel özellikleridir. Bu nedenle, Cumhurbaşkanlığı hükümet sisteminin uygulanmaya başlamasıyla, parlamenter sistemlerde önemli görev ve yetkileri olan "başbakanlık" ve "bakanlar kurulu" Türkiye Cumhuriyeti Anayasası'nda ve idari teşkilatında artık yer almamaktadır. Cumhurbaşkanlığı makamının güçlendirilmesi için Cumhurbaşkanlığı Ofisleri ve Cumhurbaşkanlığı Politika Kurulları kurulmuştur. Yeni hükümet sisteminin getirdiği bir diğer yenilik ise "Cumhurbaşkanı Yardımcılığı" makamıdır. Bu çalışmada, Türkiye Cumhuriyeti idari teşkilatı 9 Temmuz 2018 öncesi ile karşılaştırılmış, Türkiye Cumhuriyeti idari teşkilatındaki yeni aktörlerin görev ve yetkileri incelenmiştir.
\end{abstract}

Anahtar Kelimeler: Cumhurbaşkanlığı Hükümet Sistemi, Türkiye Cumhuriyeti İdari Teşkilatı, Anayasal Kurumlar, Türk Siyasal Hayatı, Kamu Politikaları

\section{Abstract}

As a result of the referendum adopted on 16 April 2017 in Turkey, the government system has changed and after the elections held on June 24, 2018, he took the oath of the President on July 9, 2018. Thus, the presidential government system began to be implemented de facto. The presidential government system has brought important innovations not only to the relations between the legislative, executive and judicial forces, but also to the administrative organization of the Republic of Turkey. Although the new government system is very similar to the presidential system, it is not exactly the same as the presidential system applied in the USA. The most important features of presidential systems are a single-headed executive and a head of state equipped with broad powers. These features are also the main features of the Presidential government system. For this reason, with the implementation of the Presidential government system, the "prime ministry" and the "council of ministers", which have important duties and powers in parliamentary systems, are not included in the Constitution and administrative organization of the Republic of Turkey. Presidential Offices and Presidential Policy Boards have been established to strengthen the office of the President. Another innovation brought by the new government system is the "Vice President" position. In this study, the administrative organization of the Republic of Turkey was compared with before July 9, 2018 and the duties and authorities of the new actors in the administrative organization of the Republic of Turkey were examined.

Keywords: Presidential Government System, Administrative Organization of the Republic of Turkey, Constitutional Institutions, Turkish Political Life, Public Policies

Özdemir, A. (2021). Cumhurbaşkanlığı Hükümet Sisteminin Türkiye Cumhuriyeti İari Teşkilatına Getirdiği Yenilikler. Journal of Academic Value Studies, 7(3), 284-297. http://dx.doi.org/10.29228/javs.51971

\footnotetext{
* Bu makale Kırgızistan'ın Bişkek şehrinde düzenlenen 2. Uluslararası İktisadi ve İdari Bilimler Kongresi'nde sözlü/çevrimiçi bildiri olarak sunulmuş, sadece özet metin olarak yayınlamıştır.

**E-mail address: ozdemir.kadir@hotmail.com
} 


\section{Giriş}

Türkiye'de 29 Ekim 1923 tarihinde cumhuriyet ilan edilmiş ve 1961 Anayasası'nın kabulüne kadar kuvvetler birliği üzerine şekillenmiş olan meclis hükümeti sistemi uygulanmıştır. Kuvvetler ayrılığı prensibi -yumuşak da olsa- ilk olarak 1961 Anayasası'nda benimsenmiş (Çilliler, 2019: 61; Yıldırım, 2017: 40), 1961 ve 1982 anayasaları ülkede parlamenter sistemin uygulanması üzerine şekillendirilmiştir. 2709 kanun numaralı 1982 Anayasası'nda birçok değişiklik yapılmış olsa da 2007 ve 2017 yıllarında yapılan değişiklikler Türkiye'nin hükümet sistemini doğrudan etkilemiştir.

2007 yılında Cumhurbaşkanının halk tarafından seçilmesi için gerekli düzenlemeler yapılmış ve daha sonrasında Cumhurbaşkanı yürütmede daha etkin olmaya başlamıştır. Cumhurbaşkanının halk tarafından seçilmesi ve sembolik yetkilerin ötesinde daha fazla yetkiye sahip olması Türkiye'deki hükümet sistemini parlamenter sistemden biraz daha uzaklaştırarak yarı başkanlık sistemine yaklaştırmıştır. 2007 referandumundan 2018 genel seçimlerine kadar geçen süreçte, Türkiye'de uygulanan hükümet sisteminin yarı başkanlık sistemi olduğunu savunanlar da vardır (Elgie, 2011: 9). 2017 yııında ise yürütmenin tek başlı olduğu, devlet başkanının daha fazla yetkilerle donatıldığı, kuvvetlerin sert ayrımına dayanan ve hükümetin, yasamanın onayına tabi olmadığı bir hükümet sistemine geçiş için gerekli anayasa değişiklikleri referandum ile kabul edilmiş, 24 Haziran 2018 milletvekilliği ve Cumhurbaşkanlığı seçimleri sonrasında Cumhurbaşkanının 9 Temmuz 2018 tarihinde yemin ederek göreve başlamasıyla Türkiye'de yeni hükümet sistemi fiilen uygulanmaya başlanmıştır. Cumhurbaşkanlığı hükümet sisteminin fiili başlama tarihini 9 Temmuz 2018 olarak kabul edenler olduğu gibi (Öner, 2019: 304), yeni sistemin 24 Haziran 2018 tarihindeki Cumhurbaşkanlığı ve milletvekilliği seçimleri ile fiilen başladığı yönünde görüşler de vardır (Turan, 2018: 43; Güler, 2018: 312; Mercimek, 2018: 131; Kara, 2019: 219; Örselli, Babahanoğlu, Bilici, 2018: 311; Esen ve Kalağan, 2020: 264; Akıncı, 2018: 2136). Ancak, 6771 sayılı Türkiye Cumhuriyeti Anayasasında Değişiklik Yapılmasına Dair Kanunun 18. maddesinde, hükümet sistemi üzerinde etkili olan anayasa değişikliklerinin büyük bir kısmının Türkiye Büyük Millet Meclisi ve Cumhurbaşkanlığı seçimleri sonucunda Cumhurbaşkanının göreve başladığı tarihte yürürlüğe gireceği belirtilmiştir. Bu nedenle yaygın görüşün aksine, Cumhurbaşkanlığı hükümet sisteminin fiili başlama tarihini 9 Temmuz 2018 (Cumhurbaşkanının yemin ederek göreve başladığı tarih) olarak kabul etmek gerekmektedir.

Cumhurbaşkanlığı hükümet sistemi olarak adlandırılan bu yeni sistem, İngiltere'de uygulanan klasik parlamenter sistemden ve Fransa'da uygulanan yarı başkanlık sisteminden çok farklı olsa da, ABD'de uygulanan başkanlık sistemi ile de tamamen aynı değildir. Ancak, üç temel hükümet sistemi içerisinde, başkanlık sisteminin özelliklerini daha çok taşımaktadır. Bu nedenle Türkiye'de uygulanan yeni hükümet sistemi, "Türk tipi başkanlık sistemi" olarak da adlandırılmaktadır. Hemen belirtmek gerekir ki, ülkelerin uyguladıkları hükümet sistemlerinin adları anayasalarda yer almamakta ve hükümet sistemleri, literatürde kuvvetler arasındaki ilişkilere göre sınıflandırılmaktadır. Bu nedenle Türkiye Cumhuriyeti Anayasası'nda da, Türkiye'de uygulanmakta olan hükümet sisteminin adı belirtilmemiştir. Ancak "Cumhurbaşkanlığı hükümet sistemi" adlandırması yaygın olarak kullanılmaktadır.

Türkiye' de özellikle 1961-2002 yılları arasında siyasal istikrarsızıklar yaşanmış, yeni hükümet sistemine geçişte, geçmişte yaşanan siyasal istikrarsızlıkların tekrar yaşanmaması, siyasal istikrarsızlıklar nedeniyle vesayet odaklarının güçlenmesini önleme ve daha etkin bir kamu yönetimi amaçlanmıştır. Bu nedenle yeni hükümet sistemi, yürütmenin istikrarını ve hükümet ömürlerini artıracak tedbirler ve özelliklere sahiptir (Akçakaya ve Özdemir, 2018: 932). Cumhurbaşkanlığı hükümet sisteminin en önemli özellikleri, yürütmenin yasama onayına tabi olmaması (hükümetin, güvenoyuna sunulmaması ve güvensizlik oyu ile sona erdirilememesi), devlet başkanının geniş yetkilerle donatılmış olması ve tek başlı bir yürütme yapısıdır. Devlet başkanının yetkilerinin artırılması ve yürütmede tek başılığın sağlanmasının doğal bir sonucu olarak 2018 yılı öncesinde Türkiye'nin idari teşkilatlanmasında yer alan bazı kurum ve kuruluşlar kapatılmıs ve Cumhurbaşkanlığı teşkilatında yeni birimler kurulmuştur.

2017 yılında yapılan anayasa değişikliklerinin büyük bir kısmı yürütme ile yasama arasındaki ilişkiler ve yürütmenin işleyişi ile ilgili olsa da, yeni hükümet sistemi ile doğrudan ilgili olmayan değişiklikler de yapılmıştır. Yasama organında yer alan kişi (milletvekillerinin) sayısının 550'den 600'e yükseltilmesi veya askeri mahkemelerin kapatılması gibi yenilikler Türkiye Cumhuriyeti idari teşkilatını doğrudan etkileyen yenilikler değildir.

16 Nisan 2017 tarihinde halkoylamasıyla kabul edilen anayasa değişikliklerinin yanı sıra 10.07.2018 tarihli Resmi Gazete'de yayınlanan 1 Sayılı Cumhurbaşkanlığı Kararnamesi de Türkiye Cumhuriyeti idari teşkilatına önemli yenilikler getirmiş̧ir. Merkezi yönetimin başkent teşkilatındaki önemli yenilikler; Cumhurbaşkanlığı Ofisleri'nin ve Cumhurbaşkanlığı Politika Kurulları'nın kurulması, Cumhurbaşkanı Yardımcısı makamı ihdas edilmesi, Başbakanlık 
makamının ve Bakanlar Kurulu'nun sona ermesi ve yerine -anayasada yer almasa da- Cumhurbaşkanlığı Kabinesi'nin kurulması, müsteşarlıkların kaldırılması ve bazı müsteşarlıkların başkanlık adını alması, Cumhurbaşkanlığı Genel Sekreterliği makamının yerine İdari İşler Başkanlığı makamının kurulması, bazı bakanlıkların birleştirilmesi ve kapatılmasıdır. Bu yeniliklere ek olarak merkeze yardımcı kuruluşlardan olan Milli Güvenlik Kurulu'nun yapısında ve merkezi yönetimin taşra teşkilatının en önemli aktörleri olan vali ve kaymakamların temsil yetkilerinde yenilikler olmuştur. Yerel yönetimler ile ilgili mevzuatlarda da yeni sisteme uyum amacıyla bazı değişiklikler yapılmış; ancak bu değişiklikler yerel yönetimlerin Türk idari teşkilatındaki yerini ve mevcut yerel yönetimlerin adlarını ve sayılarını değiştirmemiştir.

Anayasa değişikliği ve ilgili Cumhurbaşkanlığı Kararnameleri ile ortaya çıkan bu yenilikler, yeni birimlerin ve yeni makamların görev ve yetkileri, yeni hükümet sistemine geçiş ile birlikte kapatılan kurumlar ve kurullar bu çalışmanın konusunu oluşturmaktadır.

\section{Yeni Hükümet Sistemine Geçiş Öncesinde ve Sonrasında Türkiye Cumhuriyeti'nin İdari Teşkilatı}

Türkiye Cumhuriyeti ilk aşamada merkezi yönetim (genel idare) ve yerinden yönetim olmak üzere ikiye ayrılmaktadır. Merkezi idare, başkent teşkilatı ve merkezi idarenin taşra teşkilatı; yerinden yönetimler ise yer yönünden yerinden yönetimler (yerel yönetimler, mahalli idareler veya Coğrafi yerel yerinden yönetimler) ve hizmet yönünden yerinden yönetimler olmak üzere ikiye ayrılmaktadır (Nohutçu: 2015: 122). Cumhurbaşkanlığı hükümet sistemine geçiş, merkezi yönetimde önemli değişikliklere neden olmuşken, yerel yönetimlerin teşkilat yapıları üzerinde herhangi bir değişikliğe neden olmamıştır. Bu nedenle çalışmanın büyük bir kısmını, yeni hükümet sisteminin merkezi yönetime getirdiği yenilikler oluşturmaktadır.

Cumhurbaşkanlığı hükümet sistemine geçiş öncesinde, merkezi idarenin başkent teşkilatını Cumhurbaşkanı, Bakanlar Kurulu, Başbakan ve Başbakanlık, bakanlar ve bakanlıklar ile başkentteki yardımcı kuruluşlar oluşturmaktayken, Cumhurbaşkanlığı hükümet sistemine geçiş ile birlikte Başbakanlık kurumu ilga olmuş, Bakanlar Kurulu'nun yerini Cumhurbaşkanı kabinesi almıştır. Hemen belirtmek gerekir ki "Cumhurbaşkanı kabinesi" ibaresi Anayasada ve Cumhurbaşkanlığı Teşkilatı Hakkında Cumhurbaşkanlığı Kararnamesi'nde yer almamaktadır. Yeni sistemde her bir bakan, sadece Cumhurbaşkanına karşı bireysel olarak sorumludur ve bakanların müteselsil (kolektif) olarak herhangi başka bir makam veya TBMM'ye karşı sorumluluğu yoktur. Merkezi idarenin taşra teşkilatını ise il idaresi, ilçe idaresi, bucak idaresi ve bölge idareleri oluşturmaktadır. Günümüzde bucak idaresi Türkiye Cumhuriyeti idari teşkilatında fiili olarak yer almamaktadır. Bu nedenle Çağlayan’a (2012: 79) göre, bucak idaresi ibareleri ilgili mevzuatlardan kaldırımalıdır.

Cumhurbaşkanlığı hükümet sistemine geçiş öncesinde, başkent teşkilatından Cumhurbaşkanlığı teşkilatını, Cumhurbaşkanlığı Genel Sekreterliği ve Devlet Denetleme Kurulu; Başbakanlık teşkilatını, merkez teşkilat, bağlı, ilgili ve ilişkili kuruluşlar; bakanlık teşkilatlarını ise, merkez teşkilatı, taşra teşkilatı, yurt dışı teşkilatı, bağlı kuruluşlar ve ilgili kuruluşlar oluşturmaktayken; Cumhurbaşkanlığı hükümet sistemine geçiş ile birlikte, yeni makamlar ve kurumlar kurulmuş ve bazı kurumlar ve makamlar ise ilga olmuştur. Bu yenilikler ve değişikliklere ilerleyen başlıklarda yer verilmiştir.

\section{Cumhurbaşkanlığı Teşkilatındaki Yeni Birimler}

Cumhurbaşkanlığı hükümet sistemi monist bir yürütme yapısı üzerine kurulmuştur. Bu nedenle Cumhurbaşkanlığı hükümet sistemine geçiş ile birlikte en çok yenilik ve değişiklik Cumhurbaşkanlığı teşkilatında olmuştur. Cumhurbaşkanlığı Teşkilatı Hakkında Cumhurbaşkanlığı Kararnamesi, 10.07.2018 tarihli ve 30474 sayılı Resmi Gazete' de yayınlanmış ve bu kararname Cumhurbaşkanlığı teşkilatına önemli yenilikler getirmiştir.

10.07.2018 tarihi öncesinde, Cumhurbaşkanlığı; Cumhurbaşkanı, Cumhurbaşkanlığı Genel Sekreterliği ve Devlet Denetleme Kurulu'ndan oluşmaktayken (Akyılmaz, Sezginer, Kaya, 2009: 238); Cumhurbaşkanının geniş yetkiler ile donatılığı Cumhurbaşkanlığı hükümet sisteminde, Cumhurbaşkanlığına bağı çok sayıda birim kurulmuş, daha önce Cumhurbaşkanlığı makamına bağlı olmayan çok sayıdaki kuruluş ise Cumhurbaşkanlığına bağlanmıştır. Karatepe ve Altunok (2019: 4), Cumhurbaşkanlığı teşkilatını "Cumhurbaşkanlığının iç teşkilatı" (Özel Kalem Müdürlüğü, Başdanışmanlar ve Danışmanlar, İdari İşler Başkanlığı, Cumhurbaşkanı yardımcıları) ve "Cumhurbaşkanlığının, ülkenin milli politikalarını yürütücü teşkilatı" (Cumhurbaşkanlığı Politika Kurulları, Cumhurbaşkanlığı Ofisleri, Bakanlıklar ve Bağlı Kuruluşlar) olmak üzere iki gurupta sınıflandırmışlardır. 
1 sayılı Cumhurbaşkanlığı kararnamesinin, Cumhurbaşkanlığı Makamı başıklı birinci kısmında Cumhurbaşkanının hemen ardından Cumhurbaşkanlığı Özel Kalem Müdürlüğü, Cumhurbaşkanı Başdanışmanı ve Danışmanı, Özel Temsilci ve son olarak Cumhurbaşkanlığı Yüksek İstişare Kurulu’na yer verilmiştir.

Kararnamenin 2. maddesine göre, Cumhurbaşkanı Özel Kalem Müdürlüğü, "Cumhurbaşkanı makamına ilişkin hizmetleri yürütmek, Cumhurbaşkanının resmi ve özel yazışmalarını yürütmek, Cumhurbaşkanının tören, yurtiçi ve yurtdışı gezi işlerini düzenlemek ve yürütmek, Cumhurbaşkanlığı makamının protokol, halkla ilişkiler ve kurumsal iletişim hizmetlerini bünyesindeki birimler aracılığıyla yürütmek, Cumhurbaşkanının Milli Saraylar ve Devlet Arşivlerine ilişkin talimat, iş ve işlemlerini yürütmek ve Cumhurbaşkanı tarafından verilen diğer görevleri yapmakla" yetkili ve görevlidir. Özel kalem müdürü doğrudan Cumhurbaşkanı tarafından atanmaktadır.

Cumhurbaşkanı, 1 Sayılı Cumhurbaşkanlığı kararnamesine göre, kendisine danışmanlık ve verdiği diğer görevleri yapmak üzere Cumhurbaşkanı Başdanışmanı ve Cumhurbaşkanı Danışmanı atayabilmektedir. Başdanışman ve danışmanlar genellikle bir konuda uzman kişilerdir ve sayıları kararname veya anayasa ile sınırlandırılmamıştır. Buna göre atanacak kişi sayısının belirlenmesi Cumhurbaşkanının kendi tercihine bırakılmıştır. Cumhurbaşkanının özel temsilci ataması usulü de kararnamenin dördüncü maddesinde düzenlenmiştir. Cumhurbaşkanı tarafından "özel bilgi ve uzmanlık gerektiren konularda, dış ülkelerde veya uluslararası kuruluşlar nezdinde özel bir görevi ifa etmek üzere" özel temsilci görevlendirebilmektedir.

1 Sayılı Cumhurbaşkanlığı kararnamesinin getirdiği bir yenilik de Yüksek İstişare Kurulu'dur. Tüm üyelerinin Cumhurbaşkanı tarafından belirlendiği bu kurulun kurulmasıyla, kararnameye göre, "millete ve devlete hizmeti geçmiş, bilgi ve birikim sahibi kişilerin bu kazanımlarından istifade edilebilmesi" amaçlanmıştır.

\section{1. İdari İşler Başkanlığı}

1 sayılı Cumhurbaşkanlığı Kararnamesi'nin yürürlüğe girmesiyle birlikte, 2017 yılı anayasa değişiklikleriyle ilga olan Cumhurbaşkanlığı Genel Sekreterliği'nin yerine idari işler Başkanlığı kurulmuştur. Yeni hükümet sisteminde Başbakanlık kurumunun da olmaması Başbakanlık Müsteşarlığı makamını da ortadan kaldırmış ve müsteşarlığın yetkileri Cumhurbaşkanlığı İdari İ̧̧ler Başkanlığı'na devredilmiştir.

Cumhurbaşkanlığı Hükümet Sistemine geçiş öncesinde en yüksek devlet memuru Başbakanlık müsteşarıyken, yeni sistemde Cumhurbaşkanlığı İdari İşler Başkanlığı'nın en üst yetkili amiri olan İdari İşler Başkanı, en yüksek devlet memuru konumuna sahip olmuştur. Bu başkanlık, mevzuat ve Cumhurbaşkanı tarafından verilen görevleri yapmakla mükelleftir ve İdari işler Başkanı direkt olarak Cumhurbaşkanına karşı sorumludur.

1 Sayılı Cumhurbaşkanlığı Kararnamesi'nin 6. maddesine göre, İdari İşler Başkanı, Cumhurbaşkanının adına, "Anayasada belirtilen görevlerinin yerine getirilmesinde ve yetkilerinin kullanılmasında Cumhurbaşkanına gerekli olan hizmetleri sunma, TBMM ile olan münasebetlerin yürütülmesi ve kamu kurum ve kuruluşları arasında koordinasyonun sağlanması için gerekli çalışmaları yapma, devlet Teşkilatının düzenli ve etkin bir şekilde işlemesini temin edecek prensiplerin tespiti için gerekli çalışmaları yapma, iç güvenlik, dış güvenlik ve terörle mücadele konusunda koordinasyonun sağlanması için gerekli çalışmaları yapmak, yapılan çalışmaların kamuoyundaki tesirlerini izleme ve değerlendirme çalışmalarını yapmak" ile görevlidir.

Cumhurbaşkanlığı Teşkilatı Hakkında Cumhurbaşkanlığı Kararnamesi'nin ilk haline göre, İdari İşler Başkanlığı; Hukuk ve Mevzuat Genel Müdürlüğü, Personel ve Prensipler Genel Müdürlüğü, Güvenlik İşleri Genel Müdürlüğü, Destek ve Mali Hizmetler Genel Müdürlüğü olmak üzere dört birimden oluşmaktayken, 10.01.2019 tarih ve 30651 sayılı Resmi Gazete'de yayınlanan "Bazı Cumhurbaşkanlığı Kararnamelerinde Değişiklik Yapılması Hakkında Cumhurbaşkanlığı Kararnamesi” ile İdari İşler Başkanlığı'na bağlı Koruma Hizmetleri Genel Müdürlüğü kurulmuş ve İdari İşler Başkanlığı'na bağlı birim sayısı beşe yükselmiştir.

\subsection{Cumhurbaşkanı Yardımcılı̆̆ı Makamı}

Cumhurbaşkanı yardımcılığı makamı Türkiye'de ilk olarak 2017 yılında yapılan referandumla birlikte anayasada yer almıştır. Türkiye Cumhuriyeti Anayasası'nın 106. maddesine göre Cumhurbaşkanı, seçildikten sonra bir veya daha fazla sayıda Cumhurbaşkanı yardımcısı atayabilmektedir. Anayasada, kanunlarda veya herhangi bir Cumhurbaşkanlığı kararnamesinde Cumhurbaşkanı yardımcısı sayısına dair herhangi bir hüküm olmadığından, başdanışman ve danışmanlarda olduğu gibi, Cumhurbaşkanı dilediği sayıda Cumhurbaşkanı yardımcısı atayabilecektir. 
Anayasa değişiklikleri öncesinde Cumhurbaşkanına vekalet TBMM Başkanı'na aitken, anayasa değişiklikleriyle birlikte, Cumhurbaşkanlığı makamının herhangi bir nedenle boşalması halinde, Cumhurbaşkanı'nın yurt dışı seyahatlerinde ve hastalanması durumunda Cumhurbaşkanı yardımcısı, Cumhurbaşkanı'na vekalet etmektedir. Birden fazla Cumhurbaşkanı yardımcısı olduğu hallerde ise, Cumhurbaşkanlığı makamının aniden boşalması gibi bir durumda hangi Cumhurbaşkanı yardımcısının vekalet görevini üstleneceği anayasada yer almasa da Cumhurbaşkanlığı Teşkilatı Hakkında Cumhurbaşkanlığı Kararnamesi'nin 18. maddesinde en yaşlı Cumhurbaşkanı yardımcısının vekalet görevini üstleneceği belirtilmiştir.

Cumhurbaşkanı yardımcıları, Cumhurbaşkanı tarafından, milletvekili seçilme yeterliliğine sahip olan kişiler arasından atanmakta ve milletvekili olan bir kişinin Cumhurbaşkanı yardımcısı olarak atanması halinde, atanan kişinin milletvekilliği görevi sona ermektedir. Yasamada yer alan bir aktörün, aynı anda yürütmede de görev alamaması, cumhurbaşkanlığı hükümet sisteminin, kuvvetlerin sert ayrımına dayanan bir sistem olduğunun göstergelerindendir.

Cumhurbaşkanı yardımcılığının siyasi bir kimliği olmayıp, bürokrat kimliğine sahip olduğu düşünülse de (Akman, E., 2019: 51), bir siyasi parti lideri olarak da seçimlere katılabilen bir Cumhurbaşkanı tarafından doğrudan atanabilen Cumhurbaşkanı yardımcılarının siyasi bir kimlikten tamamen uzak olduğunu söyleyebilmek mümkün değildir.

\subsection{Cumhurbaşkanlığı Politika Kurulları}

Cumhurbaşkanlığı Politika Kurulları, yeni sistemin en çok dikkat çeken ve akademik çalışmalara en çok konuları arasında yer almaktadır. Politika kurullarının çok sayıda akademik çalışmaya konu olmasının birçok nedeni vardır. Bu kurulların bakanlıklar ile olan ilişkileri ve hiyerarşik konumları, politika yapım ve takip sürecindeki rolleri, diğer politika aktörlerine göre Cumhurbaşkanına yakınlık dereceleri, yeni sistemde gerçekten politika yapım sürecini hızlandırıp hızlandıramayacakları güncelliğini koruyan konular arasındadır.

Cumhurbaşkanlığı hükümet sistemine geçiş öncesinde kamu politikaları, hükümet programları ve kalkınma planları ile belirlenmekte, bu plan ve programlar meclis onayından geçtikten sonra bakanlıklar, Başbakan ve Bakanlar Kurulu tarafından uygulanmaktaydı. Kamu politikalarının uygulanması ise meclis tarafından denetlenmekteydi. Yeni sisteme geçiş ile birlikte kamu politikası aktörlerinde ve sürecinde reform yapılmış, kamu politikalarının belirlenmesinde ve uygulamaların takip edilmesinde yeni aktörler yerini almıştır. Bu aktörler politika kurulları ve ofislerdir. Kurulların ve ofislerin yapıları ile görev ve yetki alanları 1 Sayılı Cumhurbaşkanlığı Kararnamesi'nde belirtilmiştir.

Politika yapım ve değerlendirme sürecinde Cumhurbaşkanı ile doğrudan çalışan politika kurulları, en az üçer üyeden oluşmakta ve kurulların üyeleri doğrudan Cumhurbaşkanı tarafından atanmaktadır. Her kurulun başkanı Cumhurbaşkanı olsa da, kurul üyelerinden biri Cumhurbaşkanı tarafından başkanvekili olarak görevlendirilebilmektedir. Cumhurbaşkanlığı Teşkilatı Hakkında Cumhurbaşkanlığı Kararnamesi'nin 22. maddesine göre, kurullar Cumhurbaşkanı tarafından alınacak kararlar ve oluşturulacak politikalarla ilgili öneriler geliştirmekle, Cumhurbaşkanının direktifleri doğrultusunda çalışmalar yapmakla, kendi alanlarında strateji ve politika önerileri geliştirmekle, kamu kurum ve kuruluşlarına görüş vermekle ve kendi alanlarıyla ilgili Cumhurbaşkanına rapor sunmakla görevlidirler. Genel görev ve yetkilerin yanı sıra her bir politika kurulunun kendi alanlarına giren konularda spesifik görev ve yetkileri de vardır. Cumhurbaşkanlığı Politika Kurulları "Bilim, Teknoloji ve Yenilik Politikaları Kurulu, Eğitim ve Öğretim Politikaları Kurulu, Ekonomi Politikaları Kurulu, Güvenlik ve Dış Politikalar Kurulu, Hukuk Politikaları Kurulu, Kültür ve Sanat Politikaları Kurulu, Sağlık ve Gıda Politikaları Kurulu, Sosyal Politikalar Kurulu, Yerel Yönetim Politikaları Kurulu" olmak üzere dokuz tanedir.

Kamu politikalarının oluşturulmasında ve uygulanmasında kurullar öncülüğünde koordinasyon toplantıları yapılmakta ve bu toplantılara akademisyenler, sivil toplum temsilcileri, özel sektör temsilcileri, yerli veya yabancı uzmanlar davet edilebilmektedir. Kamu politikası yapım sürecinde ilgili kamu politikalarından etkilenen kesimlerin sürece dahil olabilmelerinin işlevsel politikaların üretilmesine katkı sağlayacağı beklenmektedir (Akman, E., 2019: 47).

Yeni hükümet sisteminde her ne kadar yürütme yetkisi tek başına Cumhurbaşkanında olsa da, politikaların belirlenmesi ve belirlenen politikaların bakanlıklar tarafından ne ölçüde uygulanıp uygulanamadığının tespit edilmesi ve gerekli tedbirlerin alınması Cumhurbaşkanının tek başına üstesinden gelebileceği bir iş değildir. Bu nedenle, kamu politikalarının yapım ve uygulanan politikaların incelenmesi sürecinde politika kurullarına önemli yetki ve görevler verilmiştir. Politika kurulları, Cumhurbaşkanının politikaları doğrultusunda politika ve strateji önerilerini geliştirip 
şekillendirdikten sonra Cumhurbaşkanının emir veya talimatlarıyla bakanlıklar politikaları uygulamakta ve uygulanan politikalar yine kurullar tarafından izlenmektedir. Bakanlıklar tarafından icra edilen politikaları değerlendirme ve bu politikalar ile ilgili raporları Cumhurbaşkanına sunma görevi yine kurullardadır. Öyleyse kamu politikalarının planlanma aşamasından denetim ve geri bildirim aşamasına kadar olan süreci, politika kurullarına verilen görev ve yetkilerden yola çıkılarak, şu şekilde sıralamak mümkündür:

1. Aşama: Politika kurullarının, Cumhurbaşkanının politikaları doğrultusunda politikalar belirlemesi (ön hazırlık/araştırma aşaması),

2. Aşama: Belirlenen politikaların Cumhurbaşkanına sunulması (değerlendirme, öneri ve onay aşaması),

3. Aşama: Cumhurbaşkanının onayı halinde politikaların şekillendirilmesi (planlama aşaması),

4. Aşama: Cumhurbaşkanının talimatları doğrultusunda bakanlıkların politikaları uygulaması (uygulama/icra aşaması),

5. Aşama: Bakanlıklar tarafından uygulanan politikaların, politika kurulları tarafından izlenmesi, değerlendirilmesi ve Cumhurbaşkanına politikaların uygulanması ile ilgili rapor sunulması (değerlendirme, rapor sunma ve geri bildirim aşaması),

6. Aşama: Uygulamada yaşanan aksaklıkların belirlenerek yeni politikalar geliştirilmesi.

Cumhurbaşkanlığı hükümet sistemine geçiş öncesinde, kamu politikalarının belirlenmesinde ve yürütme organının işleyişinde Başbakan ile Cumhurbaşkanı arasında uyuşmazlıkların veya uyumsuzlukların yaşanması politikalarının uygulanmasını olumsuz olarak etkilemekteydi. Ayrıca yürütmenin ihtiyaç duyduğu yasaların TBMM tarafından çıkarılmasında geçen süre politikaların gecikmesine de neden olmaktaydı. Cumhurbaşkanlığı hükümet sistemine geçiş ile birlikte tek başlı yürütme yapısı bu tür sorunları da ortadan kaldırarak merkezi yönetimde bir bütünlüğün oluşmasını sağlamıştır. Bu bütünlüğün sağlanması da bürokratik engellerin ortadan kalkmasını sağlayacaktır.

Kamu politikalarının, Şekil 1'de görülebileceği gibi, tek merkez (Cumhurbaşkanı) etrafında şekillenmesi bürokratik engelleri ortadan kaldırmakla birlikte, politika kurullarının politikaların uygulamalarını izlemesi ve Cumhurbaşkanına rapor sunması politikaların etkinliğini artıracaktır. Yeni sistemin koalisyon hükümeti kavramını ortadan kaldırmış olması, hem herhangi bir kamu politikasının uygulanma kararının alınmasında bakanlıklar arasındaki uyumsuzlukların ortaya çıkmasını hem de öncelik verilmesi gereken politikaların da geri plana atılmasını engellemektedir. 
Şekil 1. Politika yapım, uygulama ve geri bildirim sürecinde politika aktörlerinin konumu

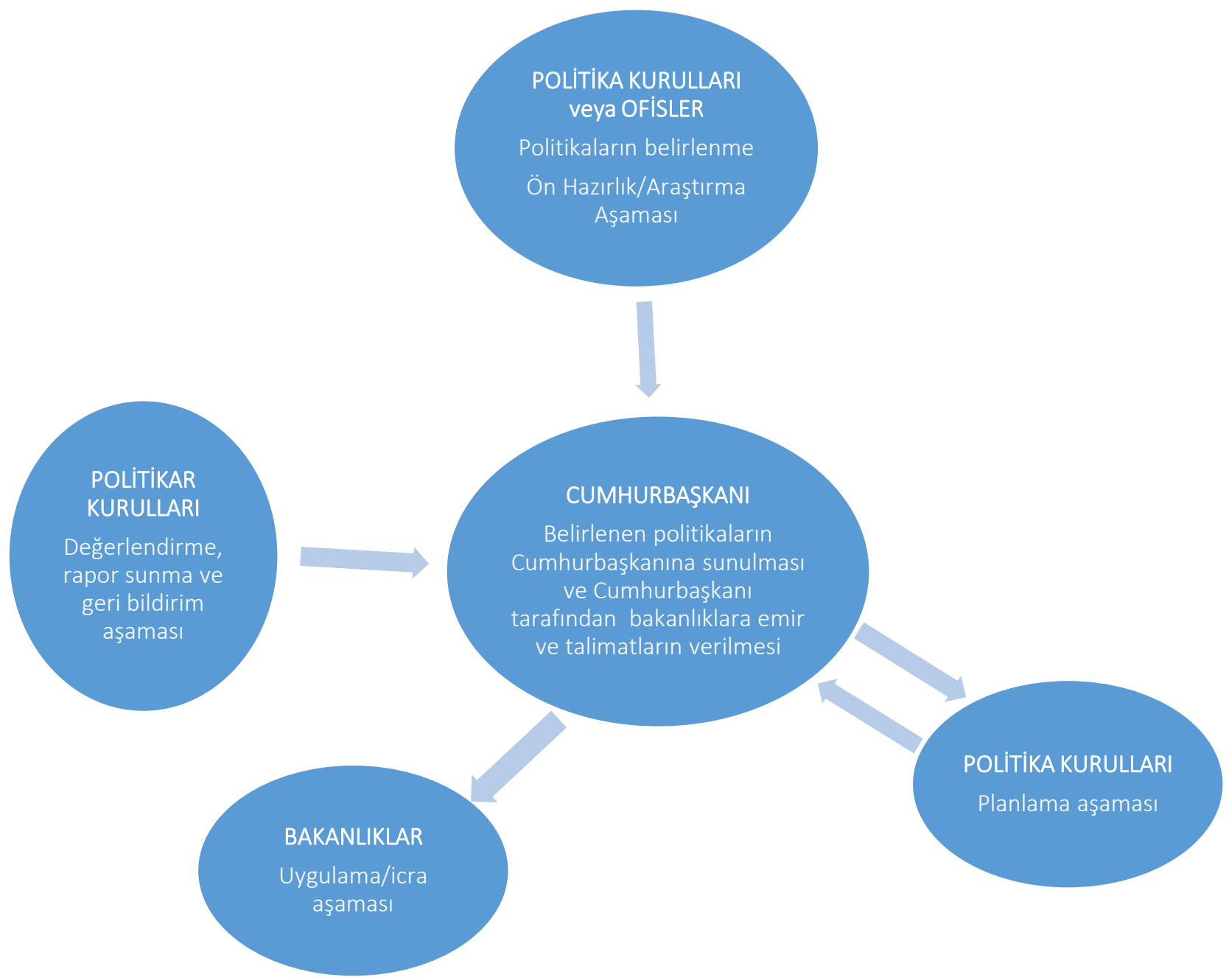

Bu görsel yazar tarafindan oluşturulmuştur.

Herhangi bir mevzuatta politika kurulları ile bakanlıklar arasında hiyerarşik bir ilişkiden bahsedilmemiş olsa da Cumhurbaşkanının her bir politika kurulunun başkanı olması, politika yapım ve politikaların izlenme süreçlerinde politika kurullarının bakanlıklar da dahil olmak üzere tüm kamu kurumlarından bilgi ve belge talep edebilmeleri, politika yapım sürecinde Cumhurbaşkanına en yakın birim olmaları, bu kurulların Cumhurbaşkanlığı teşkilatında bakanlıklardan daha üst bir noktada konumlandırıldığını ve bu nedenlerle politika yapım ve takip süreçlerinde Cumhurbaşkanına en yakın aktörün politika kurulları olduğunu söyleyebilmek mümkündür. Fakat bu konumlandırma, bakanlıkların politika kurullarının astı olduğu anlamını taşımamaktadır. Karatepe ve Altunok'a (2019: 65) göre de politika yapım sürecinde kurullardan üst bir politika aktörü mevcut değildir. Ancak belirtmek gerekir ki, politikaların uygulanıp uygulanmaması kararını vermeye Cumhurbaşkanı tek başına muktedirdir.

Kurulların görev ve yetkileri incelendiğinde, her bir kurulun politika ve strateji geliştireceği alanların belirlenmiş olduğunu görebilmek mümkündür. Herhangi bir mevzuatta hangi politika kurulunun hangi bakanlık ile ilişkili olduğu belirtilmemiş olsa da, kurulların görev ve yetkileri incelendiğinde hangi kurulun hangi bakanlıkla ilgili veya ilişkili olabileceğini tespit edebilmek mümkündür. Aşağıda yer alan tabloda kurulların ilişkili olabileceği bakanlıklar gösterilmiştir. 
Tablo 1. Politika Kurullarının görev ve yetki alanlarına göre ilgili bakanlıklar

\begin{tabular}{|c|c|}
\hline Bilim, Teknoloji ve Yenilik Politikaları Kurulu & $\begin{array}{l}\text { Sanayi ve Teknoloji Bakanlığı } \\
\text { Enerji ve Tabii Kaynaklar Bakanlığı }\end{array}$ \\
\hline Eğitim ve Öğretim Politikaları Kurulu & Milli Ĕgitim Bakanlığı \\
\hline Ekonomi Politikaları Kurulu & $\begin{array}{l}\text { Hazine ve Maliye Bakanlığı } \\
\text { Ticaret Bakanlığı } \\
\text { Enerji ve Tabii Kaynaklar Bakanlığı }\end{array}$ \\
\hline Güvenlik ve Dış Politikalar Kurulu & $\begin{array}{l}\text { İçişleri Bakanlığı } \\
\text { Dışişleri Bakanlığı } \\
\text { Milli Savunma Bakanlığı }\end{array}$ \\
\hline Hukuk Politikaları Kurulu & Adalet Bakanlığı \\
\hline Kültür ve Sanat Politikaları Kurulu & Kültür ve Turizm Bakanlığı \\
\hline Sağıık ve Gıda Politikaları Kurulu & $\begin{array}{l}\text { Sağlık Bakanlığı } \\
\text { Tarım ve Orman Bakanlığı }\end{array}$ \\
\hline Sosyal Politikalar Kurulu & $\begin{array}{l}\text { Aile ve Sosyal Hizmetler Bakanlığı } \\
\text { Gençlik ve Spor Bakanlığı } \\
\text { Çalışma ve Sosyal Güvenlik Bakanlığı }\end{array}$ \\
\hline Yerel Yönetim Politikaları Kurulu & $\begin{array}{l}\text { İçişleri Bakanlığı } \\
\text { Çevre ve Şehircilik Bakanlığı } \\
\text { Ulaştırma ve Altyapı Bakanlığı }\end{array}$ \\
\hline
\end{tabular}

Bu tablo yazar tarafindan oluşturulmuştur.

Tablo 1'de görülebileceği gibi her bir politika kurulunun ilgili veya ilişkili olduğu en az bir bakanlık vardır. Bazı kurulları üç bakanlık ile bazı kuruları ise sadece bir bakanlık ile ilişkilendirebilmek mümkündür. Yine tablodan görülebileceği gibi her bakanlığın görev alanına ilişkin muhakkak en az bir politika kurulu vardır.

\subsection{Başbakan ve Bakanlar Kurulu İbarelerinin Anayasadan Çıkarılması ile Bakanların Yeni Sistemdeki Konumu}

Cumhurbaşkanlığı hükümet sistemine geçiş öncesinde merkezi yönetimin başkent teşkilatının en önemli kurumu olan Başbakanlık, 24 Haziran 2018 tarihinden yapılan genel seçimleri sonrasında kaldırıımıştır. Yürütme yetkisi ve görevi Cumhurbaşkanı ve Bakanlar Kurulu tarafından kullanılır ve yerine getirilir hükmündeki "Bakanlar Kurulu" ibaresi anayasanın yeni halinde yer almamaktadır. Bu nedenle yeni sistemde yürütme yetkisi ve görevi sadece Cumhurbaşkanına bırakılmıştır. Cumhurbaşkanı bu yetki ve görevini, bakanlıklar, Cumhurbaşkanına bağı kurum ve kuruluşlar ve merkezi yönetimin taşra teşkilatındaki kamu aktörleri aracılığıyla yerine getirmektedir.

Parlamenter sistemlerde ve yarı başkanlık sistemlerinde yürütmenin önemli bir organı ve kolektif karar alma mercii olan bakanlar kurulu başkanlık sisteminin uygulandığı ülkelerde yer almamaktadır. Türkiye'de de anayasada yer alan tüm "Bakanlar Kurulu" kavramlarının, anayasa değişiklikleriyle birlikte kaldırılmış olması siyaset biliminde bir kavram boşluğu ve kavram kargaşasına neden olmuştur. Cumhurbaşkanının, bakanlar ile yaptığı toplantılar, anayasa değişikliklerine rağmen, yazıı veya görsel medyada zaman zaman "bakanlar kurulu toplantısı" veya "kabine toplantısı" olarak dile getirilmektedir. Bu toplantıların adlandırılma biçiminin Kartepe ve Altunok (2019: 35) tarafından teknik olarak çok yerinde olmadığı ve toplantıların "Bakanlar Toplantısı" olarak adlandırılmasının daha uygun olacağı savunulmaktadır. Her ne kadar Türkiye Cumhuriyeti Anayasası'nda yer almasa da, "Cumhurbaşkanlığı Kabinesi” ibresini Cumhurbaşkanlığı resmi internet sitesinde görebilmek mümkündür. 
Yeni sistemde bakanlıkları, Cumhurbaşkanının politikalarını uygulama aktörleri olarak tanımlayabilmek mümkündür. Bakanlıklar artık kamu politikalarının belirlenmesinden daha çok, politikaların uygulanmasında görevlidirler. Politika kurullarının kurulmasıyla birlikte, bakanlıkların politika yapım sürecinden tamamen dışlandığı akıllara gelse de politika kurularıyla bakanlıklar arasında sürekli bir istişare ve etkileşim söz konusudur. Ancak politika yapım sürecinde kurullar, bakanlıklara göre daha ön plandadır. Başka bir ifadeyle, kamu politikalarının oluşturulmasında bakanlıklar, politika kurullarına göre daha geri plandadırlar. Sobacıoğlu, Miş ve Köseoğlu da (2018: 4), Cumhurbaşkanı ve ekibinin politika belirlemede daha etkili olduğunu, bakanlıkların daha alt düzey politika yapıcısı olduklarını ve politika yapımından daha ziyade politika uygulayıcısı olduklarını düşünmektedirler. Bu nedenle bakanların siyasi kimliklerinden daha çok bürokratik kimlikleri ön plandadır ve Cumhurbaşkanlığı hükümet sistemine geçiş ile birlikte, bakanlar içerisinde siyasetçi olmayan kişilerin sayısı artmıştır. ABD'de "sekreter" olarak adlandırılan bu siyasi ve bürokratik aktörlerin, Türkiye'de "bakan" olarak adlandırımasına devam edilmektedir.

2017 yılı anayasa değişiklikleri öncesinde, anayasanın 87. maddesine göre bakanlar kurulu ve bakanlar TBMM tarafından denetlenmekteyken yeni sistemde bakanlar sadece Cumhurbaşkanına karşı sorumludurlar. Cumhurbaşkanı, milletvekili seçilme yeterliliğine sahip kişiler arasından bakan atayabilmekte ve herhangi bir gerekçeye ihtiyaç duymadan bakanların görevine son verebilmektedir. Kuvvetlerin sert ayrımı üzerine şekillenmiş olan Cumhurbaşkanlığı hükümet sisteminde, bir bakan aynı anda milletvekili olamamakta, milletvekili olan bir kişinin bakan olarak atanması halinde milletvekilliği görevi sona ermektedir. Milletvekili iken bakan olarak atanan kişi daha sonra bakanlık görevinden alındığında ise milletvekilliğine dönememektedir. Ancak bu kişinin daha sonra yapılacak bir genel seçimde yeniden milletvekili olabilmesi mümkündür.

Bakanların sadece Cumhurbaşkanına karşı sorumlu olmaları TBMM’nin bakanlar hakkında görevleriyle ilgili suç işledikleri iddiasıyla soruşturma açılmasını isteme yetkisinin olmadığın anlamına gelmemektedir. Soruşturma ve Yüce Divan'a sevk edilmeye ilişkin usul ve esaslar Anayasanın 106. maddesinde yer almaktadır.

Anayasa'nın 113. Maddesinin mülga olması ve 2017 yılı anayasa değişiklikleriyle birlikte anayasanın 106. Maddesine göre Bakanlıkların kurulması, kaldırılması, görevleri ve yetkileri, teşkilat yapısı ile merkez ve taşra teşkilatlarının kurulması artık kanunla değil Cumhurbaşkanlığı kararnamesiyle düzenlenmektedir. 24 Haziran 2018 Cumhurbaşkanlığı ve milletvekilliği seçimlerinin hemen ardından yayınlanan 1 sayılı Cumhurbaşkanlığı Kararnamesi ile bazı bakanlıklar birleştirilmiş bazıları ise tamamen kapatılmıştır. Kapatılan bakanlıkların görev ve yetkileri başka bakanlıklara devredilmiştir. Yeni sisteme geçişle birlikte bakanlık müsteşarlığı makamı kaldııılmış; ancak bakan yardımcılığı makamı devam etmektedir. Hemen belirtmek gerekir ki bakanlık teşkilatlarındaki müsteşar unvanı kaldırılmışken, Dışişleri Bakanlığının yurtdışı teşkilatında "müsteşar" unvanı devam etmektedir.

\subsection{Cumhurbaşkanlığı Ofisleri}

Cumhurbaşkanlığı hükümet sistemi ile birlikte Türk idari yapısında yerini alan Cumhurbaşkanlığı ofisleri, 1 Sayılı Cumhurbaşkanlığı Kararnamesinin 25. maddesine göre; Cumhurbaşkanlığına bağı, özel bütçeli, kamu tüzel kişiliğini haiz, idari ve mali özerkliğe sahiptirler. Cumhurbaşkanının verdiği görevleri yerine getirmek üzere kurulan Dijital Dönüşüm, Finans, İnsan Kaynakları ve Yatırım ofislerinin genel görevi planlanan kamu politikaları için araştırma yapmak ve araştırma sonuçlarını Cumhurbaşkanına sunmaktır. Her ofisin bir başkanı vardır. Ofisler, kayda değer projelerin herhangi bir bürokratik engele takılmadan Cumhurbaşkanına ulaşması açısından önemli bir konuma sahiptirler.

Cumhurbaşkanlığı politika kurulları gibi Cumhurbaşkanlığı ofisleri de kamu politikalarındaki etkinliğin artırıması amacıyla kurulmuşlardır. Başkanlık sisteminin uygulandığı bazı ülkelerde benzer örneklerle karşılaşabilmek mümkündür (Sobacıoğlu, Miş ve Köseoğlu, 2018: 6) ve ofislerin, politikalara temel olacak projelerin geliştirilmesinde kritik bir işlev üstlenmesi beklenmektedir (Turan, 2018: 74).

Kamu politikaları süreci; ön hazırlık/araştırma, değerlendirme, öneri ve onay, planlama, uygulama/icra, değerlendirme, rapor sunma ve geri bildirim olmak üzere sıralandığında, ofislerin bu süreçteki yeri Şekil 2'de görüleceği gibi ilk aşama olan ön hazırlık/araştırma aşamasıdır ve bu aşamada politika kurulları da yetkilendirilmiştir. 
Şekil 2. Ofislerin kamu politikaları sürecindeki yeri

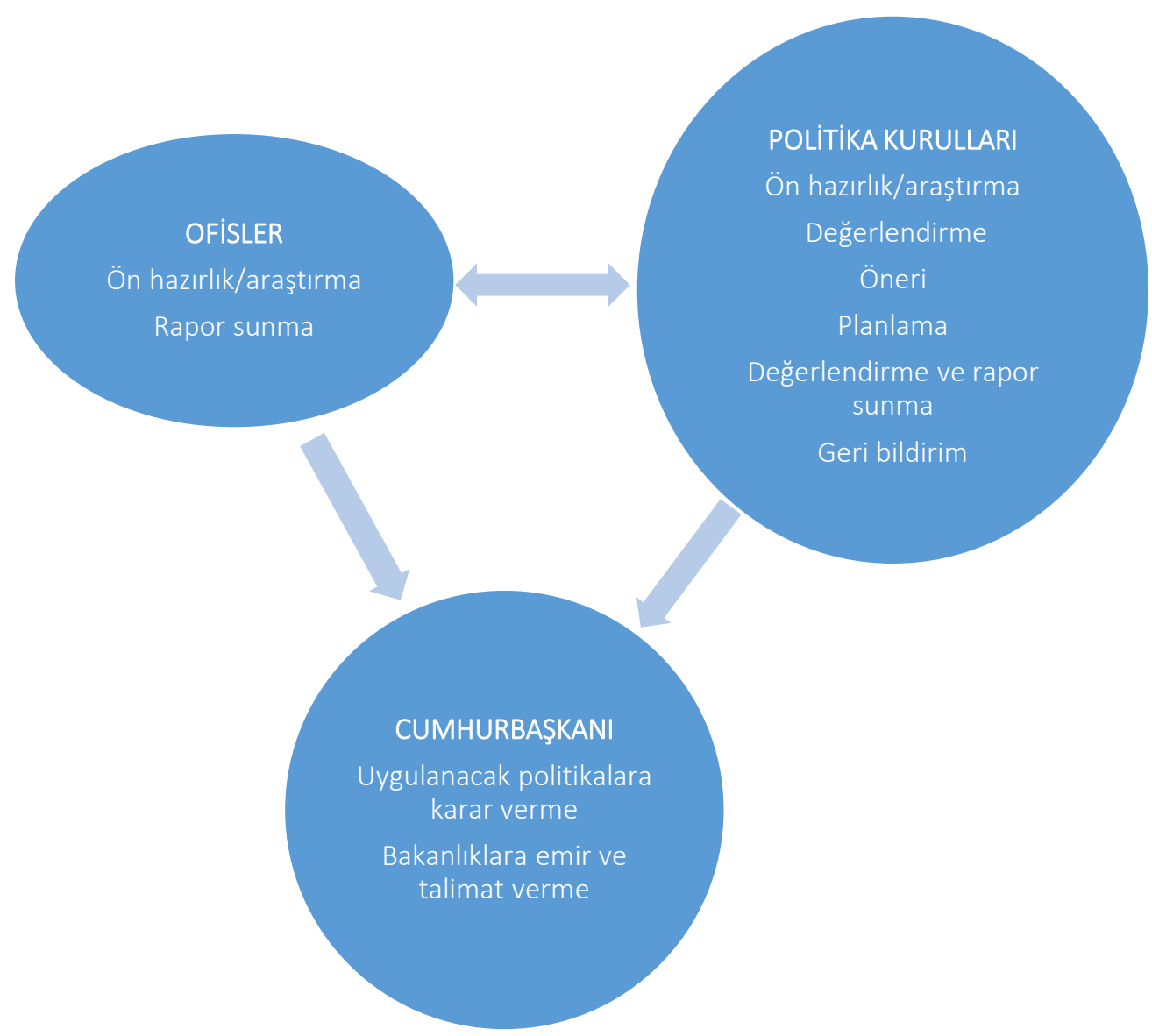

Bu görsel yazar tarafindan oluşturulmuştur.

Kamu politika süreci haricinde, ofislerin kamu kurum ve kuruluşlarına "yol gösterme", uluslar arası ve ulusal kurum ve kuruluşlar, üniversiteler, özel sektör, sivil toplum kuruluşları ile toplantılar yapma, raporlar hazırlama ve Cumhurbaşkanına sunma görevleri vardır.

Politika kurulları ile Cumhurbaşkanlığı ofisleri arasında sınırları net olan bir görev ve yetki ayrımının olmadığı düşünülse de (Erol, 2020: 121), kurulların, politika yapım, takip ve rapor sunma sürecinde ofislerden daha yetkili olduğunu ve her bir bakanlığın görev alanına ilişkin bir politika kurulu varken, her bir bakanlığın görev alanına ilişkin bir ofisin olmadığını söyleyebilmek mümkündür.

Ofislerin Türkiye Cumhuriyeti idari teşkilatındaki yerinin tespiti üzerine bazı sorunlar yaşanmaktadır. Çünkü ofisler merkezi yönetimin başkent teşkilatında yer alan Cumhurbaşkanlığı teşkilatının bir birimi olmalarına rağmen, özellikleri bakımından hizmet yönünden yerinden yönetim kuruluşlarına daha yakındır. Hizmet yönünden yerinden yönetim, teknik bilgi ve uzmanlık gerektiren bir hizmetin, kamu tüzel kişiliğine sahip ve merkezi idare dışında bir kurum tarafından gerçekleştirilmesi olarak tanımlanmaktadır (Günday, 2004: 463; Akyılmaz, Sezginer, Kaya, 2009: 352). Ayrıca, merkezi yönetimin hiyerarşik denetimi altında olmadığı halde yerel yönetim (mahalli idare) olmayan kamu kurumları da hizmet yönünden yerinden yönetim kuruluşu olarak kabul edilmektedir (Özer, Akçakaya, Yaylı, Batmaz, 2015: 350). Bu tanım ve özellikler doğrultusunda, ofislerin kamu tüzel kişiliğine ve özel bütçeye sahip olmaları, teknik bilgi ve uzmanlık isteyen bir hizmeti ifa ediyor olmaları nedeniyle hizmet yönünden yerinden yönetim kuruluşu olduklarını; ancak buna rağmen Cumhurbaşkanının hiyerarşik denetiminde olduklarını söyleyebilmek mümkündür. Zengin'e göre (2019: 15) ayrı kamu tüzel kişiliğine sahip oldukları için tüzel kişilik üzerinden yapılacak sınıflandırmaya göre bu ofisler, merkezi yönetim içinde değil hizmet yönünden yerinden yönetim kuruluşları (kamu kurumları) içinde yer almalıdırlar. Ocak (2019: 182) da ofislerin hizmet yönünden yerinden yönetim idareleri arasında olması gerektiğini savunmaktadır. 
Cumhurbaşkanlığı ofislerine kamu tüzel kişiliği verilmiş olmasına rağmen Cumhurbaşkanına, bu ofislere emir ve talimat verme yetkisinin de verilmiş olması Gözler (2019) tarafından eleştirilmekte; ya ofislere verilen kamu tüzel kişiliğinin kaldırılması ya da Cumhurbaşkanına ofisler üzerinde sadece vesayet yetkisi verilmesi önerilmektedir.

\section{Yerel Yönetimlerdeki Yenilikler}

Cumhurbaşkanlığı hükümet sistemine geçişle birlikte, yerel yönetimler (mahalli idareler) ile ilgili bazı kanunlarda, yeni sisteme uyum açısından değişiklikler yapılması zorunlu hale gelmiştir. Belediye tüzel kişiliklerinin kurulması ve sona erdirilmesine dair usul ve esaslar ile ilgili bu değişiklikler yerel yönetimlerin Türkiye Cumhuriyeti idari teşkilatı içerisindeki yerlerini değiştirmemiş; ancak Cumhurbaşkanı ile Çevre ve Şehircilik Bakanlığı'na yerel yönetimler ile ilgili bazı yetkiler verilmiştir. Daha önce Danıştay'ın görüşünün alındığı ve müşterek kararname ile yapılan bazı işlemler artık Cumhurbaşkanı kararıyla yapılabilmektedir. 5393 sayılı Belediye Kanunu'nun bazı maddelerinde yer alan "Danıştay görüşü" ve "müşterek kararname" ibareleri kaldırılmış, Cumhurbaşkanına belediye tüzel kişiliklerinin kurulması ve kaldırılmasına dair bazı yeni yetkiler verilmiştir. Öner (2019: 310), bu düzenlemeleri "teknik nitelikli düzenlemeler" olarak nitelendirmektedir.

Yerel yönetimler ile ilgili bir diğer yenilik ise İçişleri Bakanlığı ile Çevre ve Şehircilik Bakanlığı arasındaki görev ve yetki dağılımı ile ilgilidir. Yerel yönetimler ile ilgili mevzuattaki bazı değişiklikler ile İçişleri Bakanlığı ve valiliklerin görev ve yetkilerinden bazıları Çevre ve Şehircilik Bakanlığı'na devredilmiş, İçişleri Bakanlığı'na bağlı Mahalli İdareler Genel Müdürlüğü kapatılarak Çevre ve Şehircilik Bakanlığı'na bağıı Yerel Yönetimler Genel Müdürlüğü kurulmuştur. Hemen belirtmek gerekir ki, 24 Haziran 2018 tarihinden öncesinde olduğu gibi, sonrasında da mahalli idareler üzerindeki idari vesayet yetkisi İçişleri Bakanlığı'ndadır.

Yerel yönetimler ile ilgili bazı işlemlerin, herhangi bir bürokratik sürece dahil olamadan Cumhurbaşkanı kararnamesi ile yapılabilmesi, yeni sistemin ruhuna uygun olarak, işlemlerin hızlanmasını sağlayacaktır. Ancak, büyükşehirlerdeki mahalli idarelerin üç farklı kurumsal yapı ile (Çevre ve Şehircilik il müdürlüklerine bağlı yerel yönetimler şube müdürlükleri, valilikler bünyesindeki idare ve denetim müdürlükleri, yatırım izleme koordinasyon başkanlıkları) ilişkili olması karmaşık bir yapılanmaya neden olmakla birlikte, Cumhurbaşkanlığı hükümet sisteminin bürokratik bariyerleri kaldırma felsefesine uygun değildir (Öner, 2020:1348).

Yeni sistemde Cumhurbaşkanına yerel yönetimler konusunda verilen yetki sınırsı değildir. Daha açık bir ifadeyle, Anayasanın 127. maddesine göre, mahalli idarelerin kuruluş esaslarının kanunla belirtilmiş olması gerekmektedir. 5393, 5216, 6360, 5302, 5355 sayılı kanunlarda yerel yönetimlere ilişkin görev ve yetkiler belirlenmiştir. Illgili kanunlarda mahalli idareler ile ilgili bazı düzenlemelerin kanun ile yapılması gerektiği açıkça belirtilmiştir. Yine aynı kanunlarda Cumhurbaşkanı kararıyla yapılabilecek işlemler de açıkça yer almaktadır. Sonuç olarak tüm mahalli idarelerin kanunla kurulması veya belediyelerin tüzel kişiliklerinin kanunla sona erdirilmesi gerektiği yönünde bir genelleme yapmak mümkün değildir. Anayasanın 127. maddesi ile yerel yönetimler ile ilgili usul ve esasların kanunla düzenlenmesi gerektiği; ilgili kanunlardaki bazı maddelerin ise Cumhurbaşkanına bazı sınırlı yetkileri verdiği görülmektedir. Buna göre; Cumhurbaşkanı kararı ile bazı belediyelerin kurulması veya tüzel kişiliklerinin sona erdirilmesinde anayasaya veya normlar hiyerarşisine herhangi bir aykırılık görülmemektedir.

Sonuç olarak, Cumhurbaşkanlığı hükümet sistemine geçiş ile birlikte mahalli idareler ile ilgili kanunlarda birçok değişiklik yapılmış olsa da, bu değişiklikler mahalli idarelerin Türkiye Cumhuriyeti idari teşkilatı içerisindeki yerini ve teşkilat yapılarını değiştirmemiştir. Başka bir ifadeyle, yeni sisteme geçiş yerel yönetimlerin yapısında esasa ilişkin önemli değişikliklere neden olmamış (Salihoğlu, 2019: 155), iyileştirme, güçlendirme, yetki devri, hizmet sunumu ve görev tanımı üzerinde değişiklikler yapılmıştır (Akman, Ç., 2019: 2523). İçişleri Bakanlığı ile birlikte Çevre ve Şehircilik Bakanlığına da mahalli idareler ile ilgili görev ve yetkiler verilmiş, yerel yönetimler ile doğrudan ilişkili bakanlık sayısı ikiye yükselmiştir. Ayrıca bazı belediyelerin kurulması veya tüzel kişiliklerinin sona erdirilmesindeki yeni usul ve esaslar bürokrasinin azalmasını ve karar alma sürecinin hızlanmasını sağlayabilecektir. 5393 sayılı kanunun 4, 11 ve 12. maddelerinde birleşme, katılma, tüzel kişiliğin sona erdirilmesi, sınırlı bazı hallerde belediye kurulması gibi durumlarda müşterek kararnamenin ve Danıştay görüşünün gerekli olduğu hallerde artık Cumhurbaşkanı kararı yeterli olacaktır. Yeni sisteme geçiş sonrasında, merkezi yönetimin taşra teşkilatındaki mülki idare amirlerinin (vali ve kaymakamların) temsil yetkilerinde de değişiklikler yapılarak valilere ilde kaymakamlara ise ilçede devletin ve Cumhurbaşkanının temsilcisi ve idari yürütme vasıtası yetkileri verilmiştir. 


\section{Sonuç}

Türkiye'de özellikle 1960'lı yıllar sonrasında ve uzun yıllar boyunca, ülke gündeminin başat sorunları siyasal ve ekonomik istikrarsızlıklar, vesayet odaklarının siyasete sürekli müdahil olma hevesleri, çift başlı yürütme yapısından kaynaklanan krizler, sistemsel tıkanıklıklar, etkin ol(a)mayan bir kamu yönetimi ve kamu yönetimindeki bürokratik bariyerler olmuştur. Bu sorunların çoğunun hükümet sistemi değişikliği ile çözülebileceği düşüncesiyle, önce 2007 yılında yapılan anayasa değişiklikleri ile parlamenter sistemden yarı başkanlık sistemine yakın bir sisteme ve daha sonrasında 2017 yılında yapılan anayasa değişikleri ile temel üç hükümet sistemi içerisinde başkanlık sistemine daha yakın olan ve Cumhurbaşkanlığı hükümet sistemine geçilmiştir.

24 Haziran 2018 tarihinde yapılan Cumhurbaşkanlığı ve milletvekilliği seçimlerinin sona ermesi ve 9 Temmuz 2018 tarihinde Cumhurbaşkanının yemin ederek göreve başlamasıyla birlikte Türkiye'de yeni bir yönetim sistemi uygulanmaya başlanmıştır. 16 Nisan 2017 tarihinde yapılan anayasa değişikliği referandumu ile kabul edilen değişikliklerin büyük bir kısmı 24 Haziran 2018 tarihinde yapılan seçimler ve Cumhurbaşkanının yemin ederek göreve başlamasıyla birlikte yürürlüğe girmiştir. Çift başlı yürütme yapısı ve kuvvetlerin yumuşak ayrımı üzerine şekillenen parlamenter sistem veya yarı başkanlık sistemi yerine, tek başlı yürütme yapısı ve kuvvetlerin sert ayrımı üzerine şekillenen Cumhurbaşkanlığı hükümet sisteminin uygulanmaya başlaması, Başbakanlık kurumunu ve Bakanlar Kurulunu sona erdirmiş, seçimlerden kısa bir süre sonra yayınlanan 10 Temmuz 2018 tarihli ve 1 sayılı Cumhurbaşkanlığı Kararnamesi ile Türkiye Cumhuriyeti idari teşkilatında büyük değişikler yapılmıştır.

Cumhurbaşkanlığı yardımcılığı makamının ihdas edilmesi, Yüksek istişare Kurulu'nun kurulması, Cumhurbaşkanlığı Genel Sekreterliği'nin kapatılarak Idari İşler Başkanlığı'nın kurulması, bazı bakanlıkların kapatılması, birleştirilmesi veya isimlerinin değiştirilmesi, müsteşarlıkların başkanlık adını alması, merkez valiliği ve bakanlık müsteşarlıklarının kaldırılması gibi yenilikler ve değişikliklerin yanı sıra kamu politikaları sürecine, Cumhurbaşkanlığı politika kurulları ve Cumhurbaşkanlığı ofisleri olmak üzere yeni aktörler de idari teşkilata dahil edilmiştir. Bu yenilikler içerisinde özellikle kurullar ve ofislerin idari teşkilatlanmadaki konumları, hukuki statüleri ve görevleri akademik camiada dikkat konusu olmuştur.

Idari teşkilatın anlatıldı̆ı bazı görsellerde (şekil veya tablolarda) bakanlıkların, Cumhurbaşkanlığı politika kurulları ile aynı ölçüde Cumhurbaşkanına yakın oldukları görülse de politika yapım ve politikaların takibi sürecinde kurulların Cumhurbaşkanına bakanlıklardan daha yakın olduğunu söyleyebilmek mümkündür. Ayrıca, Cumhurbaşkanı, aynı zamanda tüm politika kurullarının da başkanıdır. Bu nedenlerle, Türkiye Cumhuriyeti idari teşkilatı veya Cumhurbaşkanlığı teşkilatının anlatılmaya çalışılığı görsellerde politika kurullarını Cumhurbaşkanına, bakanlıklardan daha yakın göstermek yerinde olacaktır. Cumhurbaşkanlığı ofisleri için ise daha farklı bir yorum yapmak gerekmektedir. Ofisler her ne kadar Cumhurbaşkanının milli politikaları yürütücü teşkilatı içerisinde yer alsalar da, ofisleri, Cumhurbaşkanına, kurullardan ve bakanlıklardan biraz daha uzak konumlandırmak daha doğru olacaktır. Hemen belirtmek gerekir ki kurulların, ofislerin ve bakanlıkların, Cumhurbaşkanına yakın veya uzak olarak konumlandırılması bu aktörlerin birbirleri arasındaki hiyerarşik ilişkilerin göstergesi değildir. Bir başka ifadeyle ofisler, kurulların veya bakanlıkların alt birimi veya hiyerarşik olarak astları değillerdir.

Politika kurulları yeni sistemde, Cumhurbaşkanının politika yapım ve izleme sürecinde yükünü hafifletmekte, daha etkin politikaların oluşturulmasında kilit rol oynamakta, yeni politikalar üretilirken önceki politikaların çıktılarını dikkate almakta, politika karar ve uygulama sürecindeki bürokratik engellerin ortadan kalkmasını sağlamaktadırlar. Ofisler ise kurullara göre daha az yetkiyle donatımış olsalar da, ofislerin de kamu politikalarının yeni aktörleri olduğu açıktır.

Proje aşamasındaki bir politikanın uygulanma aşamasına kadar, hatta uygulanan politikaların değerlendirme ve raporlanma aşamasına kadar Cumhurbaşkanı, Cumhurbaşkanlığı ofisleri, Cumhurbaşkanlığı politika kurulları ve bakanlıklar sıkı ilişki ve etkileşim içerisindedirler. Bu etkileşimli sistemde genel hatlarıyla ofisler ön araştırma, kurullar politika oluşturma, bakanlıklar ise politikaları uygulamakla görevlidirler. Uygulanan politikalar ise yine kurullar tarafından takip edilmekte ve politikalar ile ilgili raporlar Cumhurbaşkanına sunulmaktadır.

Cumhurbaşkanlığı ofislerinin Cumhurbaşkanlığı teşkilatı içerisinde olmasına rağmen, hizmet yönünden yerinden yönetimlerin özelliklerini taşıması, ofislerin Türkiye Cumhuriyeti idari teşkilatı içerisindeki yerinin belirlenmesinde güçlüğe neden olmaktadır. Kamu tüzel kişiliğini haiz olan Cumhurbaşkanlığı ofisleri, Cumhurbaşkanına bağlı olduğu için merkezi yönetimin başkent teşkilatında yer alıyor gibi görünse de doktrinde hizmet yönünden yerel 
yönetim kuruluşu olarak kabul edilmektedir. Bunun nedeni ise kamu tüzel kişiliğini haiz olmaları, uzmanlık ve teknik bilgi gerektiren bir hizmeti ifa ediyor olmaları ve özel bütçeli olmalarıdır.

Cumhurbaşkanlığı hükümet sistemine geçiş sadece merkezi yönetimin başkent teşkilatını değil, yerel yönetimleri de etkilemiştir. Ancak bu etki sadece eski mevzuatın yeni sisteme uyumlaştırılması için yapılan değişikliklerden ibarettir. Yeni sisteme geçiş ile birlikte yerel yönetimler üzerinde Cumhurbaşkanına bazı yetkiler verilmiş, yerel yönetimler ile ilgili bazı prosedürler daha sade hale getirilmiştir. Mahalli idareler üzerinde İçişleri Bakanlığı'nın idari vesayet yetkisi olsa da, Çevre ve Şehircilik Bakanlığı'na da yerel yönetimler ile ilgili bazı görev, yetki ve sorumluluklar yüklenmiştir. Özetle yer yönünden yerel yönetimlerin (mahalli idareler) teşkilat yapılarında ve Türkiye Cumhuriyeti idari teşkilatı içerisindeki yerinde herhangi bir değişiklik yaşanmamıştır.

Özetle, yeni hükümet sistemi, merkezi yönetimin başkent teşkilatında önemli yenilikleri beraberinde getirmiş, yerel yönetimlerin teşkilat yapıları üzerinde değişikliklere neden olmamıştır. Yeni sistem ile birlikte Cumhurbaşkanlığı Özel Kalem Müdürlüğü ve Cumhurbaşkanlığı yardımcılığı makamları ihdas edilmiş, ìdari İşler Başkanlığı, Cumhurbaşkanlığı politika kurulları, Cumhurbaşkanlığı ofisleri, Yüksek İstişare Kurulu kurulmuş, bazı bakanlıklar birleştirilmiş ve yeni bakanlıklar kurulmuş, Cumhurbaşkanlığına Bağlı Kurum ve Kuruluşlarda ve Milli Güvenlik Kurulu'nun yapısında değişiklikler yapılmış, bakanlık müsteşarlığı makamı, Başbakanlık ve Bakanlar Kurulu kaldırımıştır.

\section{KAYNAKÇA}

Akçakaya, M. \& Özdemir, A. (2018). Cumhurbaşkanlığı Hükümet Sistemi ve Siyasal İstikrar. Üçüncü Sektör Sosyal Ekonomi Dergisi, 53(3), 922-944.

Akıncı, B. (2018). Türkiye'de Kamu Politikası Oluşturma Sürecinde Yeni Aktör: Cumhurbaşkanlığı Politika Kurulları. OPUS Uluslar arası Toplum Araştırmaları Dergisi, 13(19), 2499-2532.2128-2146.

Akman, Ç. (2019). Cumhurbaşkanlığı Hükümet Sisteminde Yerel Yönetimler Yapbozu: Gelişmeler ve Öneriler. OPUS Uluslar arası Toplum Araştırmaları Dergisi, 9(16), 2499-2532.

Akman, E. (2019). Cumhurbaşkanlığı Hükümet Sisteminde Kamu Politikası Aktörleri. Paradoks Ekonomi, Sosyoloji ve Politika Dergisi, 15(1), 35-54.

Akyılmaz, A.; Sezginer, M. \& Kaya, C. (2019). Türk İdare Hukuku. Seçkin Yayıncılık, Ankara.Çilliler, Y. (2019). Karşılaştırmalı Siyasal Sistemler Türkiye-ABD. Nobel Yayınevi, Ankara.

Çağlayan, R. (2012). Yeni Anayasa ve İdari Teşkilat. Liberal Düşünce, 17(66), 77-81.

Elgie, R. (2011). "Semi-Presidentialism: An Increasingly Common Constitutional Choice". R. Elgie, S. Moestrupand Y. S. Wu (Eds.), Semi-Presidentialism and Democracy. First Published, New York: Palgrave Macmillan, pp. 1- 20.

Erol, Ö.F. (2020). Cumhurbaşkanlığı Hükümet Sisteminde Cumhurbaşkanlığı Politika Kurulları. Marmara Üniversitesi Hukuk Fakültesi Hukuk Araştırmaları Dergisi, 26(1), 107-130.

Esen, E. \& Kalağan, G. (2020). Cumhurbaşkanlığı Hükümet Sistemi’nde Merkezi İdarenin Dönüşümü. Süleyman Demirel Üniversitesi Vizyoner Dergisi, 11(Ek), 260-277.

Gözler, K. (2019). "Cumhurbaşkanlığı Hükûmet Sisteminin Uygulamadaki Değeri: Bir Buçuk Yıllık Bir Bilanço", www.anayasa.gen.tr/cbhs-bilanco.htm, (Yayın Tarihi: 27 Aralık 2019).

Güler, T. (2018). Cumhurbaşkanlığı Hükümet Sistemi ve Kamu Yönetimine Etkileri. Balıkesir Üniversitesi Sosyal Bilimler Enstitüsü Dergisi, 21(39), 299-322.

Günday, A. (2004). İdare Hukuku. İmaj Yayınevi, Ankara.

Kara, T. (2019). Cumhurbaşkanlığı Hükümet Sistemi: "Siyasal ve Bürokratik Dönüşüm". Uluslararası Batı Karadeniz Sosyal ve Beşeri Bilimler Dergisi, 3(2), 218-234.

Karatepe, Ş \& Altunok, H. (2019). Cumhurbaşkanlığı Politika Kurulları Kamu Politikasının Yeni Aktör ve Süreçleri. Püf Yayıncılık, Ankara.

Mercimek, Ş. (2018). Bürokratik Vesayet Anlayışına Cumhurbaşkanlığı Hükümet Sistemi'nin Etkisi. Uluslararası Batı Karadeniz Sosyal ve Beşeri Bilimler Dergisi, 2(2), 131-149. 
Nohutçu, A. (2015). İdare Hukuku. Savaş Yayınevi, Ankara.

Ocak, K. (2019). Cumhurbaşkanlığı Kararnamesi ile Idari Vesayet Yetkisi Düzenlenmesinin Bir Örneği Olarak Cumhurbaşkanlığı Ofisleri. Anayasa Yargısı, 36(1), 163-193.

Öner, ş. (2019). Cumhurbaşkanlığı Hükümet Sisteminin Yerel Yönetim Mevzuatına Etkileri. Çanakkale Onsekiz Mart Üniversitesi Uluslar arası Sosyal Bilimler Dergisi, 4(2), 303-332.

Öner, Ş. (2020). Cumhurbaşkanlığı Hükümet Sistemi: Merkez-Yerel Illişkilerde Kurumsal Değişim ve Dönüşüm. Elektronik Sosyal Bilimler Dergisi, 19(75), 1335-1353.

Örselli, E.; Babahanoğlu, V. \& Bilici, Z. (2018). Kamu Politikalarında Yeni Aktörler: Cumhurbaşkanlığı Politika Kurulları ve Ofisleri. Turkish Studies Economics, Finande and Politics, 13(3), 303-318.

Özer, M.A.; Akçakaya, M.; Yaylı, H. \& Batmaz, N.Y. (2015). Kamu Yönetimi, Adalet Yayınevi, Ankara.

Salihoğlu, E. (2019). Cumhurbaşkanlığı Hükümet Sisteminde Yerel Yönetimler ve Denetimi. Marmara Belediyeler Birliği Kültür Yayınları, İstanbul.

Sobacı, M.Z. \& Miş, N. \& Köseoğlu, Ö. (2018). Türkiye'nin Yeni Yönetim Modeli ve Cumhurbaşkanlığı Teşkilatı. Seta Perspektif, Sayı 206, 1-6.

Turan, M. (2018). Türkiye'nin Yeni Yönetim Düzeni: Cumhurbaşkanlığı Hükümet Sistemi. Sosyal Bilimler Araştırma Dergisi, 7(3), 42-91.

Yıldıım, H. (2017). Parlamenter Sistem Krizleri ve Cumhurbaşkanlığı Hükümet Sistemi. Pozitif Yayınları, İstanbul.

Zengin, O. (2019). Cumhurbaşkanlığı Hükümet Sistemi ve İdari Yapıya Etkisi. Emek Araştırma Dergisi, 10(15), 1-24.

\section{Makalede Kullanılan Mevzuat}

Bazı Cumhurbaşkanlığı Kararnamelerinde Değişiklik Yapılması Hakkında Cumhurbaşkanlığı kararnamesi, Kararname Numarası: 27, Yayımlandığı Resmî Gazetenin Tarihi ve Sayısı: 10.01.2019 - 30651.

Belediye Kanunu, Kanun Numarası: 5393, Kabul Tarihi: 03.07.2015, Yayımlandığı Resmî Gazete Tarihi ve Sayısı: 13.07.2005 - 25874

Büyükşehir Belediyesi Kanunu, Kanun Numarası: 5216, Kabul Tarihi: 10.07.2004, Yayımlandığı Resmî Gazete Tarihi ve Sayısı: 23.07.2004 - 25531

Cumhurbaşkanlığı Teşkilatı Hakkında Cumhurbaşkanlığı Kararnamesi, Cumhurbaşkanlığı Kararnamesinin Sayısı: 1, Yayımlandığı Resmî Gazetenin Tarihi ve Sayısı: 10.07.2018 - 30474

II Özel İdaresi Kanunu, Kanun Numarası: 5302, Kabul Tarihi: 22.02.2005, Yayımlandığı Resmî Gazete Tarihi ve Sayısı: 04.03.2005 - 25745

Mahalli İdare Birlikleri Kanunu, Kanun Numarası: 5355, Kabul Tarihi: 26.05.2005, Yayımlandığı Resmî Gazete Tarihi ve SayısI: $11.06 .2005-25842$

On Dört Illde Büyükşehir Belediyesi ve Yirmi Yedi İlçe Kurulması ile Bazı Kanun ve Kanun Hükmünde Kararnamelerde Değişiklik Yapılmasına Dair Kanun, Kanun Numarası: 6360, Kabul Tarihi: 12.11.2012, Yayımlandığı Resmî Gazete Tarihi ve Sayısı: 06.12.2012 - 28489.

Türkiye Cumhuriyeti Anayasası, Kanun Numarası: 2709, Kabul Tarihi: 18.10.1982, Yayımlandığı Resmî Gazete Tarihi ve Sayısı: 09.11.1982 -17863 (Mükerrer)

Türkiye Cumhuriyeti Anayasasında Değişiklik Yapılmasına Dair Kanun, Kanun Sayısı: 6771, Kabul Tarihi: 21.01.2017, Yayımlandığı Resmî Gazete Tarihi ve Sayısı: 11.02.2017 - 29976 